\title{
PREDICTORS, DETERMINANT GROUPS, AND PARTICIPATORY BUDGETING
}

\author{
Maja Klun ${ }^{1}$, Jože Benčina ${ }^{2}$
}

\begin{abstract}
Recent developments in local public finance management in Slovenia indicate the local governments' growing interest in introducing participatory budgeting as a decisionmaking tool, wherein part of local resources are used with citizen participation. Usually, the literature on participation budgeting analyses its effects, but our main research objective was to analyze the possible determinants influencing its implementation. The influence of political factors, sociodemographic factors, economic factors, and the capability of municipalities are examined here using binary logistic regression to predict a dichotomous dependent variable from a set of predictor variables. In binary logistic regression, predictable variables are the probability of one category being chosen. In this case, the authors calculated the probability that a municipality, described by selected prediction variables, would implement a participatory budget. The results of the analysis suggest six indicators that impact the probability of participatory budgeting adoption, proving the influence of four determinants on the decision to adopt such a measure.
\end{abstract}

KEY WORDS: Participatory budgeting, Determinants, Local government, Slovenia, Participation.

\section{INTRODUCTION}

In history, public administration has been guided in various ways, such as Weberian State, new public administration, its evolution and future changes, the post-Weberian state, and in the last decade good governance. The Council of Europe defines good governance as "the responsible conduct of public affairs and management of public resources ..." (The Council of Europe, 2018). It sets out twelve principles to summarize the factors that constitute good governance. Amongst them, the principle of "fair conduct of elections, representation and participation" determines that citizens can participate in decision-making and influence resource allocation. Since the principle

\footnotetext{
${ }^{1}$ Faculty of Public Administration, University of Ljubljana, Gosarjeva ulica 5, 1000 Ljubljana, Slovenia. E-mail: maja.klun@fu.uni-lj.si. ORCID: 0000-0002-1025-9134.

${ }^{2}$ Faculty of Public Administration, University of Ljubljana, Gosarjeva ulica 5, 1000 Ljubljana, Slovenia. E-mail: joze.bencina@fu.uni-lj.si. ORCID: 0000-0002-3676-6214.
} 
of "sound financial management" includes public consultation (Council of Europe, Centre of Expertise, 2018), it also addresses citizen participation in resource allocation. OECD also emphasized public participation in the policy-making process as one of the means for promoting good governance and boosting democratic government to be more open and responsive to citizens' needs (OECD, 2001). Moynihan (2007) suggests three arguments as to why citizen participation has become interesting in the last few decades. All of these are related to the development of public administration, social conditions that encourage citizens to participate more, dissatisfaction with traditional hierarchical bureaucratic models, and the search for the democratic ideal.

Participatory budgeting ("PB") is a natural implementation of citizen participation in resource allocation. With the participation of citizens, the decisions of policy makers are made more legitimate, the accountablility and confidence in public decisions are improved. Activating citizens is a rather demanding task, especially if not previously experienced or if a public participation was not required in the past. Citizens' empowerment is crucial to building confidence in decisions. Policy makers can be more sure that they are doing the right thing. and, at the same time, they are better aware of their role and the importance of their active participation in society. According to the some researchers, participation in budgetary processes has advantages and disadvantages. The most common positive effects mentioned include improved transparency, higher citizen satisfaction, providing better service to citizens (see, e.g., Shah, 2007; Russon, 2016; Wampler, 2000; Allegretti, Herzberg, 2004; Radu, 2019). Most criticism of participation relates to the reduced power of elected representatives in decision-making bodies (Memeti, Kreci, 2016; Allegretti, Herzberg, 2004). In addition, the most common obstacle to the implementation of $\mathrm{PB}$ in practice is a public that lacks any interest in it, lacks any understanding of the overall financial framework and proposals focusing on fulfilling individual wishes, and the exploitation of influential stakeholders to achieve their proposals is also not present. (Klun, Benina, 2022).

The paper is aimed to identify any possible determinants that influence the spread of PB in Slovenian local governments. The literature examines various determinants of PB determinants at the local (eg, Ebdon, 2000; Zhang, Liao 2011; Liao, Zhang, 2012; Mbithi, Ndambuki, Juma, 2019; Klimovský, Svidroňová, 2021) or central level of government (eg, Harrison, Sayogo, 2014; Rios, Benito, Bastida, 2016), or determinants of civic engagement as such (eg, Arvantidis, 2017). 
Our main contribution to the state of the art was, similarly to Rios, Benito, and Bastida (2016), grouping the determinants into four groups, and consequently verifying them at the local level. Furthermore, this paper contributes to the analysis with more variables to determine the most significant variable in each group.

Considering the results of the previous research, our general hypothesis - based research was contructed as follows:

$\mathrm{H}$ : Political circumstances, sociodemographic situation, the level of economic development, and the ability of a municipality influence the probability of adoption of $\mathrm{PB}$.

Here, four subhypotheses $(\mathrm{H} 1, \mathrm{H} 2, \mathrm{H} 3, \mathrm{H} 4)$ were structured into several sub-subhypotheses in order to cope with the complexity of the observed concepts.

H1: The political circumstances of a municipality influence the probability of adoption of the $\mathrm{PB}$, structured into sub-subhypotheris below:

$\mathrm{H}_{11}$ : The characteristics of a municipality's mayor influence the PB adoption, and

$\mathrm{H}_{12}$ : The level of democracy achieved by a municipality influences the adoption of the PB.

$\mathrm{H} 2$ : The socio-demographic situation in a municipality influences the probability of the PB adoption, structured into sub-subhypotheris below:

$\mathrm{H}_{21}$ : The knowledge capability of a municipality influences the PB adoption.

$\mathrm{H}_{22}$ :The difference between immigrants and emigrants in a municipality influences the PB adoption.

$\mathrm{H}_{23}$ : Demography influences the adoption of PB.

$\mathrm{H}_{24}$ : The health situation influences the adoption of PB.

$\mathrm{H}_{25}$ : Social cohesion influences the $\mathrm{PB}$ adoption

H3: The level of economic development of a municipality influences the probability of adoption of the $\mathrm{PB}$, structured into sub-subhypotheris below:

$\mathrm{H}_{31}$ : The economic growth of a municipality influences the decision for the PB adoption.

$\mathrm{H}_{32}$ : The economic level of a municipality influences the PB adoption.

H4: The ability of a municipality influences the probability of the PB adoption.

$\mathrm{H}_{41}$ : The organizational capacity of a municipality influences the adoption of the PB.

$\mathrm{H}_{42}$ : The financial capability of a municipality influences the PB adoption. 
Binary logistic regression is applied to predict the impact of selected independent variables on the probability that a municipality is implementing a participatory budget. The subhypotheses are tested by the four groups of determinants formulated as independent variables for four regression models.

The paper is structured into the following sections: a short literature review on the PB determinants follows the introduction, the core is a section on research methodology, and presentation of the findings. The final part is comprised by a discussion and conclusions.

\section{THE DETERMINANTS OF PARTICIPATORY BUDGETING}

Several scholars have examined the importance and role of citizen participation in public governance. They try to determine the roles and influence of citizens and the advantages of participation. (i.e., Andersen, van Kempen, 2003; Bloomfield, Collins, Fry, Munton, 2001; Buček, Smith, 2000; Cooper, Bryer, Meek, 2006; Fung, 2006; Yang, Callahan, 2007; Hayrapetyan, 2019). Arvanitidis (2017) delineates several determinants that influence civic engagement at individual and systemic levels. Individual-level determinants comprise resources and values, demographic attributes such as age, a region's size, education level, wealth, and trust. At a systemic level, the determinants mentioned are social structure and income disparities. Other researchers also stressed the importance of communication channels, especially the use of IT as a tool to involve citizens (i.e., Wellman, Boase, Chen, 2002; Warren, Sulaiman, Jaafar, 2014; Thomas, Streib, 2005; Saebo, Rose, Flak, 2008; Yetano, 2015; Nitzsche, Pistoia, Elsäßer, 2012).

This paper focuses on the PB as a direct citizen participation in the budgeting process. Citizens' empowerment rises the accountability of the budget. Furthermore, it is a means of educating citizens on budgetary procedures.. Miller et al. (2019) stress that researchers define the PB differently and consider various kinds of citizen participation. The broader definition by Wampler (2007, p. 21) is that the PB is "a decisionmaking process through which citizens deliberate and negotiate over the distribution of public resources". A more precise definition is determined by Sintomer et al. (2012), wherein five additional criteria are added: the discussion of financial/budgetary processes, the involvement of a decentralized district with an elected body and some power over administration and resources, the recurrence of the process over the years, the inclusion of public deliberation, and some accountability regarding the 
results of the process. In our research, the second definition of the PB is applied.

Despite various definitions of the $\mathrm{PB}$, the relevant literature usually classifies its effects, such as better transparency, citizen satisfaction, better services, more equitable and efficient allocation, higher long-term fiscal stability, etc. (i.e. Shah, 2007; Russon, 2016; Wampler, 2000; Birskyte, 2013; Allegretti, Herzberg, 2004; Tanaka, 2007). Other research focuses on the obstacles in the PB implementation (i.e., Birskyte, 2013; Švaljek, RašićBakarić, Sumpor, 2019) or comparison of the processes (Manes-Rossi et al., 2021; Lehtonen, 2021; Džinić, Svidroňová, Markowska-Bzducha, 2016). Research on the determinants that influence the PB is rather not obvious and, in most cases, is based on case studies from various countries, and as a result, it is difficult to make direct comparisons. However, indications from other studies are important and therefore, are considered in the research herein. After having summarized the findings of other research, it is apparent that researchers discussed several types of determinants, i.e., political, sociodemographic, economic and organizational (Ebdon, 2000; Zhang, Liao, 2009; Zhang, Liao, 2011; Liao, Zhang, 2012; Rios, Benito, Bastida, 2016; Klimovský, Svidroňová, 2021). Some recentresearch evaluate the influence of COVID-19 as well (i.e. Bardovič, Gašparík, 2021; Cho, Jérôme, Maurice, 2021).

Political factors include institutional structure, political heterogeneity, political culture, and other political variables (Ebdon, 2000; Zhang, Liao, 2011; Rios, Benito, Bastida, 2016; Harrison, Sayogo, 2014; Wang, 2001; Goetz, Gaventa, 2001; Klimovský, Svidroňová, 2021). Previous research demonstrates that lower corruption and higher political competition positively affect the participatory budgeting (i.e. Harrison, Sayogo, 2014; Mbithi, Ndambuki, Juma, 2019; Ebdon, 2000). The capability of local government, such as the number of employees, budget transparency, data openness, etc. (Carlitz, 2013, de Renzio, Wehner, 2017) is reported to be likely to influence the adoption of participatory budgeting. However, there is no uniform conclusion taken on this fact. The positive influence of budget transparency was also determined by Rios, Benito, and Bastida (2016).

Sociodemographic determinants are variables such as population, education level, and average income (Harrison, Sayogo, 2014; Ebdon 2000; Zhang, Yang 2009; Liao, Zhang 2012; Halachmi, Holzer, 2010; Rios, Benito, Bastida, 2016). Some of the mentioned research finds that higher income and better education improve citizen participation (i.e. Harrison, Sayogo, 2014), while other studies do not find them statistically significant (i.e. Rios, Benito, Bastida, 2016). 
In most of the research, the economic determinants are significant and are comprised by factors such as economic development and financial capability, which depend on budget revenues, the municipality's own resources, and budget flexibility (Liao, Zhang, 2012; Raich, 2005; Harrison, Sayogo, 2014; Rios, Benito, Bastida, 2016). Some researchers report a positive correlation between economic factors and participatory budgeting; however, the evidence is not confirmed uniformly.

Our research extends the above research by elaborating on the determinants that influence participatory budgeting at the local level. It is the first research to include variables that have not been tested before, and to identify the main determinants in each group.

\section{CONCEPT AND METHODS APPLIED}

In Slovenia, there are 212 municipalities, of which 11 are urban municipalities. Municipalities in Slovenia differ according to several criteria (area, number of inhabitants, revenues and expenditures etc.). The PB implementation process is set out in the municipal charters and in the instructions for drawing up the municipal budget. The legislation stipulates that the municipality are obliged to submit a draft budget for a public debate before it is adoption by a municipal council. In order to supplement this general provision, The Local Self-Government Act was amended in 2018 to allow municipalities to determine the amounts used for funding projects proposed by citizens in a drafting process of a municipal budget proposal. The first attempt to introduce participatory budgeting in Slovenia was made in the municipality of Maribor in 2015. Despite clearly defined steps and standards, the attempts failed because the citizens did not respond appropriately. The first successful implementation of $\mathrm{PB}$ at the local level in Slovenia was reported in 2016, when two municipalities (Ajdovščina and Komen) launched the PB process for the fiscal years 2018 and 2019. The evaluation of the first two successful attempts showed that 43 projects in the total amount of EUR 480 thousand were carried out. After the first two attempts and the legislative changes in 2018, several new cases of participatory budgeting could be observed, especially since 2019. In 2020, up to 26 municipalities adopted the participatory budgeting. Analysis of the PB process and practice in Slovenian municipalities brings conclusion that all municipalities published a call for proposals and the rules for submitting initiatives, set other conditions, limited the total amount of the budget determined for citizen participation, and then collected proposals for investment spending (Klun, Benčina, 2022). 
Herein, the PB concept is based on the theory of broader concept of the citizen participation theory. The determinants of PB reflect a more general concept of the determinants of citizen participation. In the conceptualization of this research, authors considered four groups of determinants suggested by the previous research: political, socio-demographic, economic, and organizational (Ebdon, 2000; Rios, Benito, Bastida, 2016). Considering the administrative factor as the municipal capability, including the financial and organizational capability of a municipal administration, this paper devises a conceptual model with the following four groups of determinants:

- political;

- socio-demographic;

- economic development;

- municipal capability.

Research assumptions, supported by evidence of the previous research, were to define the influence of the determinants on the behavior of municipalities regarding the adoption of PB.

The aim of this research was to prove that the factors influencing the decision-making process of participatory budgetary procedures in Slovenian municipalities influenced the PB decision-making process.

The response (dependent) variable (the PB behaviour of municipalities) was measured applying a simple dummy variable with the value "1" for municipalities using the PB approach, and " 0 " for others.

In order undertand the basic meaning of the determinants, an operational model was proposed here to elucidate the impact of the indicators that make up the determinants of the PB behavior. The model is presented in two tables. Table 1 shows the higher-level structure of the model with the determinants and themes that form the basis for the above subhypotheses.

Table 1: Operational model of $P B$ determinants

\begin{tabular}{|c|c|c|c|c|}
\hline No. & Determinants & No. & Theme & Source \\
\hline \multirow[b]{2}{*}{1} & \multirow[b]{2}{*}{$\begin{array}{c}\text { political } \\
\text { determinants }\end{array}$} & 1.1 & $\begin{array}{c}\text { characteristic of } \\
\text { mayor }\end{array}$ & \multirow{2}{*}{$\begin{array}{l}\text { (Harrison, Sayogo, 2014; } \\
\text { Mbithi, Ndambui, Juma, } \\
\text { 2019; Rios, Benito, Bastida, } \\
\text { 2016; Wang, 2001; } \\
\text { Klimovský, Svidroňová, } \\
\text { 2021; Kukučkova, Bakoš, } \\
\text { 2019) }\end{array}$} \\
\hline & & 1.2 & $\begin{array}{l}\text { level of } \\
\text { democratic } \\
\text { governance }\end{array}$ & \\
\hline
\end{tabular}




\begin{tabular}{|c|c|c|c|c|}
\hline \multirow{5}{*}{2} & \multirow{5}{*}{$\begin{array}{c}\text { socio- } \\
\text { demographic } \\
\text { determinants }\end{array}$} & 2.1 & $\begin{array}{l}\text { knowledge } \\
\text { capability }\end{array}$ & \multirow{5}{*}{$\begin{array}{c}\text { (Rios, Benito, Bastida, 2016, } \\
\text { Sintomer et al., 2016; Liao, } \\
\text { Zhang, 2012; Ebdon, 2000; } \\
\text { Zhang, Yang, 2009) }\end{array}$} \\
\hline & & 2.2 & $\begin{array}{l}\text { immigrant } \\
\text { surplus }\end{array}$ & \\
\hline & & 2.3 & demography & \\
\hline & & 2.4 & health & \\
\hline & & 2.5 & social cohesion & \\
\hline \multirow[b]{2}{*}{3} & \multirow{2}{*}{$\begin{array}{l}\text { economic } \\
\text { development }\end{array}$} & 3.1 & economic growth & \multirow{2}{*}{$\begin{array}{c}\text { (Rios, Benito, Bastida, 2016; } \\
\text { Harrison, Sayogo, 2014; } \\
\text { Raich, 2005; Svaljek et al., } \\
\text { 2019) } \\
\end{array}$} \\
\hline & & 3.2 & level of economy & \\
\hline \multirow{2}{*}{4} & \multirow{2}{*}{$\begin{array}{l}\text { municipal } \\
\text { capability }\end{array}$} & 4.1 & $\begin{array}{c}\text { organizational } \\
\text { capability }\end{array}$ & \multirow{2}{*}{$\begin{array}{l}\text { (Liao, Zhang, 2012; Raich, } \\
\text { 2005; Harrison, Sayogo, } \\
\text { 2014; Carlitz, 2013) }\end{array}$} \\
\hline & & 4.2 & $\begin{array}{l}\text { financial } \\
\text { capability }\end{array}$ & \\
\hline
\end{tabular}

Source: the authors

As a prediction variable, indicators in public databases were used (the Statistical Office of the Republic of Slovenia - SURS, the Ministry of Finance, the National Institute of Public Health - NIJZ) and a private database (ISSO) and these available publicly- structured data enabled to compare the municipalities using different factors.

Using the appropriate indicators from the database, the PB determinants were defined operationally. (Table 2).

Table 2: Variables of the operational model of the PB determinants

\begin{tabular}{|c|c|c|c|}
\hline ID & Indicator & Meaning & Source \\
\hline 1.1.a & $\begin{array}{l}\text { independent } \\
\text { mayor }\end{array}$ & $\begin{array}{l}\text { dummy variable for independent/party } \\
\text { mayor support }\end{array}$ & \multirow{5}{*}{$\begin{array}{c}\text { local } \\
\text { elections } \\
2018\end{array}$} \\
\hline 1.1.b & incumbent mayor & $\begin{array}{l}\text { dummy variable for incumbency (at least } \\
\text { twice) }\end{array}$ & \\
\hline 1.2.a & share of votes & share of votes for the elected mayor & \\
\hline 1.2.b & $\begin{array}{l}\text { number of } \\
\text { candidates }\end{array}$ & $\begin{array}{l}\text { number of candidates at mayoral elections } \\
2018\end{array}$ & \\
\hline 1.2.c & election turnout & voter turnout at 2018 mayoral elections & \\
\hline 2.1.a & $\begin{array}{l}\text { number of } \\
\text { graduates }\end{array}$ & number of graduates per 1,000 inhabitants & SiStat \\
\hline
\end{tabular}




\begin{tabular}{|c|c|c|c|}
\hline 2.1.b & brain drain index & $\begin{array}{l}\text { the ratio between the change in the number } \\
\text { of persons in employment with tertiary } \\
\text { education and the number of graduates }\end{array}$ & ISSO \\
\hline 2.1.c & scholarship sum & $\begin{array}{l}\text { the sum of scholarships paid over five } \\
\text { years, calculated per 1,000 inhabitants }\end{array}$ & ISSO \\
\hline 2.2.a & attractiveness & $\begin{array}{l}\text { attractiveness for immigration, a five-year } \\
\text { average difference between immigrants } \\
\text { and emigrants per 1,000 inhabitants }\end{array}$ & ISSO \\
\hline 2.3.a & aging index & $\begin{array}{l}\text { the ratio between the old (aged } 65 \text { or over) } \\
\text { and the young population (aged } 0 \text { to 14) }\end{array}$ & ISSO \\
\hline 2.3.b & age dependency & $\begin{array}{l}\text { the ratio between the sum of old (aged } 65 \\
\text { or over) and the young population (aged } 0 \\
\text { to 14) and the number of the working-age } \\
\text { population (aged } 15 \text { to } 64 \text { ) }\end{array}$ & SiStat \\
\hline 2.3.c & natural increase & the natural change of population & SiStat \\
\hline 2.3.d & mortality & $\begin{array}{l}\text { the ratio between the number of deaths in } \\
\text { the observed calendar year and the number } \\
\text { of all inhabitants in the middle of the same } \\
\text { year, multiplied by } 100,000\end{array}$ & NIJZ \\
\hline 2.4.a & suicide mortality & $\begin{array}{l}\text { the ratio between the number of suicide } \\
\text { deaths in the observed calendar year and } \\
\text { the population in the middle of the same } \\
\text { year multiplied by } 100,000\end{array}$ & NIJZ \\
\hline 2.4.b & $\begin{array}{l}\text { children's } \\
\text { physical } \\
\text { condition }\end{array}$ & $\begin{array}{l}\text { The physical condition of children (age } \\
\text { 6-14) is the deviation of the average result } \\
\text { of body fitness tests of a municipality } \\
\text { from the national average calculated in } \\
\text { percentiles ( } 50 \text { for national average) }\end{array}$ & NIJZ \\
\hline 2.4.c & absenteeism & $\begin{array}{l}\text { the ratio between the total number of days } \\
\text { of sick leave of the population and the } \\
\text { number of all persons in employment in the } \\
\text { observed calendar year }\end{array}$ & NIJZ \\
\hline 2.4.d & alcoholism & $\begin{array}{l}\text { the ratio of the number of people } \\
\text { participating in the Health and Health Care } \\
\text { Survey who answered that they got drunk } \\
\text { at high risk at least once in the last } 12 \\
\text { months and the number of all people who } \\
\text { answered the questionnaire multiplied by } \\
100 \\
\end{array}$ & NIJZ \\
\hline 2.5.a & the convicted & $\begin{array}{l}\text { the convicted adults and juveniles per } \\
1,000 \text { inhabitants }\end{array}$ & SiStat \\
\hline 2.5.b & home help & $\begin{array}{l}\text { share of home help beneficiaries among } \\
\text { people aged } 65 \text { and over }\end{array}$ & NIJZ \\
\hline 2.5.c & neighbourhood & $\begin{array}{l}\text { neighbourhood cohesion - whether the } \\
\text { respondents get neighbourhood help easily }\end{array}$ & NIJZ, EHIS \\
\hline 2.5.d & associations & associations per 1,000 inhabitants & ISSO \\
\hline 3.1.a & income growth & $\begin{array}{l}\text { percentage change in the total income of } \\
\text { the municipal economy in five years }\end{array}$ & ISSO \\
\hline
\end{tabular}




\begin{tabular}{|c|c|c|c|}
\hline 3.1.b & company growth & $\begin{array}{c}\text { average annual number of newly registered } \\
\text { business entities per 1000 inhabitants }\end{array}$ & ISSO \\
\hline 3.1.c & $\begin{array}{c}\text { fast growing } \\
\text { companies index }\end{array}$ & $\begin{array}{c}\text { the share of fast-growing companies } \\
\text { amongst all companies }\end{array}$ & ISSO \\
\hline 3.2.a & value-added & $\begin{array}{c}\text { gross value of fixed capital formation per } \\
1,000 \text { inhabitants }\end{array}$ & SiStat \\
\hline 3.2.b & investment & private investment per capita & SiStat \\
\hline 3.2.c & $\begin{array}{c}\text { development } \\
\text { index }\end{array}$ & index of development level of municipality & ISSO \\
\hline 3.2.d & $\begin{array}{c}\text { labour market } \\
\text { index }\end{array}$ & $\begin{array}{c}\text { including job growth, youth unemployment, } \\
\text { and expenditure on employment promotion }\end{array}$ & ISSO \\
\hline 4.1.a & $\begin{array}{c}\text { employee } \\
\text { number }\end{array}$ & $\begin{array}{c}\text { online local budget transparency } \\
\text { assessment }\end{array}$ & MF \\
\hline 4.1.b & OLBT & public investment per capita & ISSO \\
\hline 4.2.a & public investment & puta \\
\hline 4.2.b & expenses & public administration expenses per capita & MF \\
\hline 4.2.c & expenses growth & $\begin{array}{c}\text { five-year growth of public administration } \\
\text { expenditure as a percentage }\end{array}$ & ISSO \\
\hline 4.2.d & $\begin{array}{c}\text { own revenues } \\
\text { growth }\end{array}$ & own revenues growth & ISSO \\
\hline 4.2.e & debt servicing & $\begin{array}{c}\text { debt servicing as a share of own-source } \\
\text { revenues }\end{array}$ & ISSO \\
\hline 4.2.f & financial & $\begin{array}{c}\text { the ratio between the revenues that the } \\
\text { municipality can generate and the current } \\
\text { expenses of the municipality }\end{array}$ & ISSO \\
\hline
\end{tabular}

Source: the authors

Considering the choice of methodological approach, the authors have continued to pursue the research objective of determining whether participation budgetary implementation can be predicted on the basis of variables defining four PB determinants.. Therefore, a binary logistic regression was chosen to predict independent variables from the predicted variables. For a binary logistic regression, the predicted variable is the probability of taking one of the categories. It facilitated the use of categorical predictors and avoidance of the assumptions on the distribution of the predictor variables. In the case herein, the authors calculated the probability that a participatory budget would be implemented by the municipality (the one described by selected prediction variables).

The subhypotheses that the four determinants have an impact on the probability of PB adoption was verified by using four regression models for the determinants defined by the variables presented in Table 1 . The 
general hypothesis was confirmed if all the determinants had a statistically significant impact on the probability of the PB adoption. This was a case where, for each determinant, at least one of the subhypotheses devised below was verified. Likewise, a subhypothesis was verified by confirming at least one hypothesized (sub-subhypotheses) indicator's statistically significant odds ratio.

With the first regression model, authors examined the indicators of the political determinant (subhypothesis $\mathrm{H}_{1}$ ). They explored whether the characteristics of the mayor and the level of democratic governance in a municipality prove any influence on the PB adoption. Therefore, in this research two sub-subhypotheses are devised: $\mathrm{H}_{11}$ : the characteristics of the mayor influences the $\mathrm{PB}$ adoption, and $\mathrm{H}_{12}$ : the democratic level in municipality influences the $\mathrm{PB}$ adoption. $\mathrm{H}_{11}$ has been confirmed to determine whether mayor independence or elected officials or stronger voter support affect the likelihood of adoption of the PB. Similarly, $\mathrm{H}_{12}$ has confirmed whether the number of candidates and the participation in the last elections affected the probability of adopting the PB.

As explained above, the second regression model comprised five elements of the socio-demographic determinant $\left(\mathrm{H}_{2}\right)$. Accordingly, five sub-subhypotheses are stated therefore: $\mathrm{H}_{21}$ : the knowledge capability of a municipality affects the PB adoption (confirmed whether the number of graduates per 1,000 inhabitants, the brain drain index or the scholarship sum per 1,000 inhabitants prove any effect on the probability of the PB adoption), $\mathrm{H}_{22}$ : the difference between immigrants and emigrants in a municipality prove affecting the PB adoption (confirmed whether the coefficient of attractiveness influenced the probability of the PB adoption), $\mathrm{H}_{23}$ : demography proves effects on the PB adoption (confirmed whether the aging index, the age dependency ratio, the natural increase coefficient or the mortality coefficient have any effects on the probability of PB adoption), $\mathrm{H}_{24}$ : health is affecting the PB adoption (confirmed whether the suicide mortality coefficient, children's physical condition, absenteeism or alcoholism affect the probability of the $\mathrm{PB}$ adoption), and $\mathrm{H}_{25}$ : social cohesion proves effects on the PB adoption (confirmed whether the number of convicted per 1,000 inhabitants, the level of home help, neighbourhood cohesion or the number of associations per 1,000 inhabitants affected the probability of the PB adoption).

In economic development $\left(\mathrm{H}_{3}\right)$, two elements were observed, namely economic growth and economic level. The two sub-subhypotheses were: $\mathrm{H}_{31}$ : the economic growth of a municipality proves effects on the decision in 
favour of the PB adoption (confirmed whether the income growth, company growth or the fast-growing companies index affect the probability of $\mathrm{PB}$ adoption), $\mathrm{H}_{32}$ : the level of economy in a municipality affect the $\mathrm{PB}$ adoption (confirmed whether value-added, private investment per capita, companies per 1,000 inhabitants or labour market index influenced the probability of the PB adoption).

The impact of municipal capability $\left(\mathrm{H}_{4}\right)$ on $\mathrm{PB}$ adoption was hypothesized by two sub-subhypotheses: $\mathrm{H}_{41}$ : the organizational capability of a municipality proves effects on the PB adoption (confirmed whether the number of employees in municipal administration or OLBT influenced the probability of the $\mathrm{PB}$ adoption), and $\mathrm{H}_{42}$ : the financial capability of a municipality proves effects on the $\mathrm{PB}$ adoption (confirmed whether the public investment per capita, public administration expenses per capita, public administration expenses growth, own revenues growth, debt servicing as a share of ownsource revenues or the financial independence coefficient prove any effects on the the probability of the PB adoption).

\section{KEY FINDINGS AND DISCUSSION}

The statistics applied includes all Slovenian municipalities (212), with the PB adoption data for 2020 and all other variables - except for 2018 election data - for 2019. The descriptives of the variables are integrated into the result tables of the regression analysis.

For comparison purposes, the descriptive statistics was included into the regression analysis's results table. Accordingly, the tables include $\mathrm{N}$, Minimum, Maximum, Mean, Standard Deviation, regression coefficient B, the significance of the coefficientp, and the odds ratio OR. Since the interpretation of the results of the regression analysis is more clear and concise with comparable standard variables, the authors here have standardized all scale predictors. However, descriptives for original variables are reported.

Table 3: Descriptive statistics and regression parameters for political determinant

\begin{tabular}{|c|c|c|c|c|c|c|c|c|c|}
\hline ID & H & N & Min & Max & Mean & SD & B & p & OR \\
\hline 1.1.a & $\mathrm{H}_{11}$ & 212 & 0 & 1 & 0.59 & 0.493 & 0.623 & 0.191 & 0.536 \\
\hline 1.1.b & $\boldsymbol{H}_{11}$ & 212 & 0.00 & 1.00 & 0.47 & 0.500 & -1.177 & $\mathbf{0 . 0 2 8}$ & 3.246 \\
\hline 1.2.a & $\mathrm{H}_{12}$ & 212 & 0.00 & 100.00 & 14.68 & 25.07 & -0.128 & 0.623 & 0.880 \\
\hline
\end{tabular}




\begin{tabular}{|c|l|c|c|c|c|c|c|c|c|}
\hline $1.2 . \mathrm{b}$ & $\mathrm{H}_{12}$ & 212 & 1 & 20 & 3.29 & 2.354 & 0.322 & 0.106 & 1.380 \\
\hline 1.2.c & $\boldsymbol{H}_{12}$ & 211 & 35.5 & 84.2 & 56.7 & 9.64 & -0.627 & $\mathbf{0 . 0 1 4}$ & $\mathbf{0 . 5 3 4}$ \\
\hline
\end{tabular}

Legend: ID - variable ID of Table 2; $\mathrm{H}$ - hypothesis, OR - odds ratio.

Source: the authors

As explained above, the first subhypothesis $\left(\mathrm{H}_{1}\right)$ stated that the political determinant influenced PB initiative in a municipality. The subhypothesis was verified with a binary logistic regression model for the probability that the PB adoption response variable comprises five predictor variables. For two out of five predictor variables, the model expressed a statistically significant impact on the probability of the PB adoption with the incumbency (1.1.b) and election turnout variables (1.2.c). This allowed to confirm both political determinant sub-subhypotheses, $\mathrm{H}_{11}$ for the characteristics of the mayor and $\mathrm{H}_{12}$ for the level of democratic governance in the municipality. This is in line with research by Wang (2001), while some other research did not lead to the same conclusion (i.e., Rios, Benito, Bastida, 2016). A municipality was more than three times as likely to opt for a PB initiative (odds ratio $=3.246$ ) with an incumbent mayor than with a newcomer. Contrarily, for each percentage point of increase in voter turnout, there was almost a double in the odds that the municipality would not adopt PB (odds ratio $=0.534$ ). Additional analysis indicated that both variables had a weak negative correlation. Furthermore, the independent sample $t$-test manifested a statistically significant difference between the voter turnout in municipalities with an incumbent mayor and the voter turnout in municipalities with a newcomer, with a lower turnout for incumbent mayors. Consequently, this could hardly account for the lower election turnout for the higher ratio of the PB adoption. Thus, both the lower turnout and the probability of PB adoption should be attributed to incumbency.

For the sociodemographic determinant subhypothesis $\left(\mathrm{H}_{2}\right), 16$ predictor variables were considered, while three of them expresed a significant impact on the probability of adoption of the PB adoption probability (Table 4).

Table 4: Descriptive statistics and regression parameters for the sociodemographic determinant

\begin{tabular}{|c|c|c|c|c|c|c|c|c|c|}
\hline ID & $\mathrm{H}$ & $\mathrm{N}$ & Min & Max & Mean & SD & $\mathrm{B}$ & $\mathrm{p}$ & OR \\
\hline 2.1.a & $\mathrm{H}_{21}$ & 211 & 10.8 & 64.7 & 45.5 & 7.23 & -0.037 & 0.908 & 0.964 \\
\hline 2.1.b & $\mathrm{H}_{21}$ & 211 & 0.05 & 1.25 & 0.49 & 0.155 & -0.303 & 0.418 & 0.738 \\
\hline
\end{tabular}




\begin{tabular}{|c|l|c|c|c|c|c|c|c|c|}
\hline 2.1.c & $\mathrm{H}_{21}$ & 211 & 0.00 & 895146 & 6057 & 11734 & -0.152 & 0.635 & 0.859 \\
\hline 2.2.a & $\boldsymbol{H}_{22}$ & 211 & -12.45 & 20.07 & -0.87 & 5.071 & 0.696 & $\mathbf{0 . 0 4 5}$ & $\mathbf{2 . 0 0 5}$ \\
\hline 2.3.a & $\mathrm{H}_{23}$ & 211 & 64.90 & 353.1 & 133.8 & 37.96 & 1.140 & 0.076 & 3.128 \\
\hline 2.3.b & $\mathrm{H}_{23}$ & 211 & 30.10 & 68.5 & 52.54 & 4.854 & 0.333 & 0.363 & 1.395 \\
\hline 2.3.c & $\mathrm{H}_{23}$ & 211 & -96.39 & 48.12 & -0.975 & 19.696 & 1.258 & 0.113 & 3.517 \\
\hline 2.3.d & $\mathrm{H}_{23}$ & 211 & 615.20 & 1819.8 & 1007.1 & 213.04 & 0.676 & 0.281 & 1.966 \\
\hline 2.4.a & $\mathrm{H}_{24}$ & 211 & 0.00 & 92.63 & 24.66 & 16.257 & -0.158 & 0.658 & 0.854 \\
\hline 2.4.b & $\boldsymbol{H}_{24}$ & 212 & 43.96 & 55.73 & 49.89 & 1.900 & 0.662 & $\mathbf{0 . 0 3 2}$ & $\mathbf{1 . 9 3 8}$ \\
\hline 2.4.c & $\mathrm{H}_{24}$ & 212 & 4.77 & 29.86 & 15.21 & 3.212 & 0.129 & 0.698 & 1.138 \\
\hline 2.4.d & $\mathrm{H}_{24}$ & 211 & 0.37 & 5.97 & 2.13 & 0.857 & -0.115 & 0.695 & 0.892 \\
\hline 2.5.a & $\mathrm{H}_{25}$ & 211 & 0.40 & 13.1 & 2.99 & 1.561 & -0.011 & 0.971 & 0.989 \\
\hline 2.5.b & $\boldsymbol{H}_{25}$ & 212 & 0.00 & 4.39 & 1.53 & 0.958 & 0.618 & $\mathbf{0 . 0 1 8}$ & $\mathbf{1 . 8 5 5}$ \\
\hline 2.5.c & $\mathrm{H}_{25}$ & 211 & 39.8 & 89.4 & 69.5 & 8.71 & -0.152 & 0.578 & 0.859 \\
\hline 2.5.d & $\mathrm{H}_{25}$ & 211 & 5.66 & 39.0 & 11.9 & 3.59 & -0.645 & 0.119 & 0.524 \\
\hline
\end{tabular}

Legend: ID - variable ID of Table 2; $\mathrm{H}$ - hypothesis, OR - odds ratio.

Source: the authors

Consequently, $\mathrm{H}_{21}$ (knowledge capacity) and $\mathrm{H}_{23}$ (demography) were rejected. The first result is opposite to the results obtained by Harrison and Sayogo (2014) and similar to Rios, Benito, and Bastida (2016), while demography in other research gained similar (i.e., Liao and Zhang, 2012) or opposite results (i.e., Ebdon, 2000; Zhang and Yang, 2009; Rios, Benito, and Bastida, 2016). With significant predictor attractiveness (ID = 2.2.a, $\mathrm{p}=$ 0.045 , ods ratio $=2.005)$, sub-subhypothesis $\mathrm{H}_{22}$ was verified meaning that immigration impacted the PB adoption. That implied that the odds for the PB adoption in a municipality were more than two times higher for each point of immigration surplus. Sub-subhypothesis $\mathrm{H}_{24}$ on the health status impacting the $\mathrm{PB}$ adoption was also verified, with $\mathrm{p}=0.032$ and the odds ratio $=1.938$ for children's physical condition (ID = 2.4.b). This implied that a higher children's physical condition indicator almost doubled the odds of PB adoption at each point. The model also confirmed sub-subhypothesis $\mathrm{H}_{25}$ on social cohesion. The home help variable showed almost doubled odds (ID $=2.5 . \mathrm{b}, \mathrm{p}=0.018$, odds ratio $=1.855$ ) of the $\mathrm{PB}$ adoption for each point of the higher home help indicator. The probability of the PB adoption was higher in municipalities with migration surplus, better physical condition of children, and better care for elder people. These results were in line with other researches suggesting that elder people and population diversity prove a positive influence on participation (i.e., Arvanitidis, 2017; Rios, Benito, and Bastida, 2016). 
The impact of the economic determinant on the probability of $\mathrm{PB}\left(\mathrm{H}_{3}\right)$ adoption was subhypothesized by two sub-subhypotheses, $\mathrm{H}_{31}$ for economic growth and $\mathrm{H}_{32}$ for the level of economy (Table 5).

Table 5: Descriptive statistics and regression parameters for the determinant of economic development

\begin{tabular}{|c|c|c|c|c|c|c|c|c|c|}
\hline ID & $\mathbf{H}$ & $\mathbf{N}$ & Min & Max & Mean & SD & B & p & OR \\
\hline 3.1.a & $\mathrm{H}_{31}$ & 211 & -0.44 & 3.18 & 0.30 & 0.345 & -0.485 & 0.172 & 0.616 \\
\hline 3.1.b & $\mathrm{H}_{31}$ & 211 & -12.23 & 11.29 & 1.13 & 2.485 & 0.244 & 0.317 & 1.276 \\
\hline 3.1.c & $\mathrm{H}_{31}$ & 211 & 0.00 & 73.57 & 29.96 & 14.724 & 0.207 & 0.434 & 1.230 \\
\hline 3.2.a & $\mathrm{H}_{32}$ & 211 & 0.17 & 51.28 & 6.40 & 6.218 & & & \\
\hline 3.2.b & $\mathrm{H}_{32}$ & 211 & 0.00 & 6008 & 1389 & 1368 & -0.174 & 0.538 & 0.840 \\
\hline 3.2.c & $\mathrm{H}_{32}$ & 212 & 0.34 & 1.47 & 1.00 & 0.173 & 0.381 & 0.207 & 1.464 \\
\hline 3.2.d & $\boldsymbol{H}_{32}$ & 211 & 0.09 & 0.83 & 0.31 & 0.152 & 0.507 & $\mathbf{0 . 0 3 7}$ & $\mathbf{1 . 6 6 0}$ \\
\hline
\end{tabular}

Legend: ID - variable ID of Table 2; $\mathrm{H}$ - hypothesis, OR - odds ratio.

Source: the authors

As no variables of economic growth had statistically significant regression coefficients, $\mathrm{H}_{31}$ was rejected. Due to multicollinearity, the variable value added (ID = 3.2.a) in the $\mathrm{H}_{32}$ part of the model needed to be excluded. With a statistically significant variable labour market index (ID $=3.2 . \mathrm{d}, \mathrm{p}=$ 0.037 , odds ratio $=1.660$ ) the sub-subhypothesis $\mathrm{H}_{32}$ - that economic level impacted the adoption of the PB - was confirmed. The result implied that the labour market index raised the odds of the PB adoption by 1.660 times for each point increase. Municipalities with a higher labour market index were more likely to adopt the PB. The conclusions here are similar to Liao and Zhang (2012), while the results are opposite to the results obtained by certain other researchers (Harrison, Sayogo, 2014; Rios, Benito, Bastida, 2016).

The municipality's capacity included two elements: organisational and financial capacities (Table 6). 
Table 6: Descriptive statistics and regression parameters for the capability of a municipality

\begin{tabular}{|c|c|c|c|c|c|c|c|c|c|}
\hline ID & $\mathbf{H}$ & $\mathbf{N}$ & $\mathbf{M i n}$ & $\mathbf{M a x}$ & Mean & SD & $\mathbf{B}$ & $\mathbf{p}$ & OR \\
\hline 4.1.a & $\mathrm{H}_{41}$ & 212 & 2.33 & 551.28 & 24.27 & 45.780 & 0.243 & 0.174 & 1.276 \\
\hline 4.1.b & $\mathrm{H}_{41}$ & 212 & 0.00 & 5.00 & 3.67 & 0.930 & 0.141 & 0.600 & 1.151 \\
\hline 4.2.a & $\mathrm{H}_{42}$ & 212 & 81.91 & 1146 & 406.6 & 186.9 & -0.280 & 0.347 & 0.755 \\
\hline 4.2.b & $\mathrm{H}_{42}$ & 212 & 62.73 & 1022 & 155.8 & 92.64 & 0.128 & 0.701 & 1.137 \\
\hline 4.2.c & $\mathrm{H}_{42}$ & 212 & -0.33 & 0.95 & 0.05 & 0.165 & 0.099 & 0.680 & 1.104 \\
\hline 4.2.d & $\mathrm{H}_{42}$ & 212 & -0.12 & 1.02 & 0.07 & 0.108 & -0.043 & 0.851 & 0.958 \\
\hline 4.2.e & $\mathrm{H}_{42}$ & 212 & 0.00 & 0.62 & 0.05 & 0.052 & -0.283 & 0.474 & 0.753 \\
\hline 4.2.f & $\boldsymbol{H}_{42}$ & 212 & 0.29 & 2.33 & 0.99 & 0.328 & 0.458 & $\mathbf{0 . 0 3 5}$ & $\mathbf{1 . 5 8 1}$ \\
\hline
\end{tabular}

Legend: ID - variable ID of Table 2; $H$ - hypothesis, OR - odds ratio.

Source: the authors

No statistically significant predictors of organisational capability were detected. Thus, $\mathrm{H}_{41}$ - that the organizational capability of a municipality influenced the PB adoption - was rejected. With the statistically significant predictor of financial independence (ID $=4.2 . \mathrm{f}, \mathrm{p}=0.035$, odds ratio $=1.581$ ), $\mathrm{H}_{42}$ - that the financial capability of a municipality influenced the PB adoption - was confirmed. Each point of increasing the financial independence rised the probability of the PB adoption 1.581 times. Financial capability also shows the influence in research by Liao and Zhang (2012) or partly by Rios, Benito, and Bastida (2016).

As mentioned above, at least one indicator for each determinant was found as statistically impacting the probability of the PB adoption. Accordingly, the findings confirmed the general hypothesis of the research introduced in this paper, that political circumstances, the sociodemographic situation, the level of economy, and the capacity of a municipality apparently impacted the probability of PB the adoption.

In summary, the analysis results suggest six indicators that affect the likelihood of the PB adoption and show the influence of four factors on decision to adopt the PB. Political impact is expressed through incumbency. Mayors who hold their office for several terms are more likely to initiate or support PB initiatives. The influence of social demographic determinants is covered by immigration surplus, the children's physical condition indicator, and the share of elder people receiving home help. The other two determinants, economic level and municipal capability, influence 
the adoption of the PB with the labour market index and the financial independence coefficient.

The political influence demonstrates the mayor's attitude towards innovative initiatives. More experienced mayors are more likely to develop innovative approaches to foster citizen participation and the legitimacy of local government. The socio-demographic indicators that influence PB adoption indicate a municipality's care for its citizens, pointing to the municipal government's concern for specific population groups. Similar holds true for the economic indicator labour market index, which mainly measures labour market development. Financial capability, expressed by the financial independence index, also influences the PB adoption. As it correlates with attractiveness, the children's physical conditon indicator, and the labour market index, a conclusion appears that the probability of the PB adoption mainly depends on the mayors' and local governments' attitude towards citizens.

\section{CONCLUSION}

Citizens' involvement in public-interest decisions is increasingly important. However, only a few of numerous studies concerned the advantages and disadvantages of participation, explore the determinants that influence PB at the local level.

In order to identify the factors influencing the adoption of $\mathrm{PB}$, this paper defines a conceptual model that contains four determinants based on previous research: political, sociodemographic, economic, and municipal capability. The model here is operationalized as a three-level structure with 11 themes and 36 indicators. Hence, the authors devised a general model of determinants of PB. On the one hand, the PB determinants were introduced into a unified definition, and on the other, the most appropriate indicators were defined within an open framework.. Thereupon, the authors have contributed to a unified approach to enable comparable research actions, including specific conditions in different environments. Moreover, in the paper authors applied the model for the case of Slovenian municipalities and provided solid and valuable results.

The results of applying the model to Slovenian municipalities suggest six indicators that impact the probability of adoption of the PB, proving the influence of the four determinants on the decision to adopt the PB. Political impact is expressed through incumbency. Mayors who hold their office for several terms are more likely to initiate or support the PB initiatives. The 
influence of social demographic determinants is covered by immigration surplus, the children's body fitness indicator, and the share of elder people receiving home help. The other two determinants, economic level and municipal capability, influence the PB adoption with the labour market index and the financial independence coefficient.

Some of the determinants that proved their signifincy in other research, in this research they turned out to be insignificant (i.e. budget transparency) and vice versa (i.e. socio-demographic factors). When interpreting the results, certain limitations of this research need also to be taken into account. The number of municipalities that adopted the PB is low, while the time frame of variables and the dummy variable are not in line, and the time lag is still an open question. Therefore, a conclusion is that despite a long list of variables, other circumstances also influence the decision to introduce the PB at the local level. After all, results of the research introduced in this paper demonstrated the fact that the determinants of the PB adoption expressed the attitude of municipalities towards their citizens. There is still room for further research, especially on the mayors' attitude towards the $\mathrm{PB}$, the national legislation adopted, public administration tradition, citizens' willingness to participate, etc. Some of them are already indicated in recent studies on the PB process and citizens' attitude towards the PB (i.e. Švaljek et al., 2019), while others have not been verified yet (i.e. public administration tradition). Moreover, it must be noted that it is difficult to obtain many local variables, which may inhibit further research and comparisons in different countries. Nevertheless, some determinants are common and influential in almost all studies, despite the different cultures and traditions, especially concerning those connected to the financial capability of local governments.

Despite the limitations and obstacles mentioned to the research, certain practical recommendations can be made for policymakers and citizens. It is apparent that better financial capacity, demografic diversity, and economic development promote better citizen engagement. The voter turnout brings interesting results, as mayors who have served several terms of office seem to be more willing to adopt the PB, probably also as part of their political pre-election promotion. Citizens should therefore fulfil their commitments and exercise their powers in preparing the budget.

\section{Acknowledgment:}

The authors acknowledge the financial support from the Slovenian Research Agency (Research Programme - Development of an Efficient and Effective Public Administration System, no. P5-0093). 


\section{REFERENCES}

ALLEGRETTI, G. and HERZBERG, C. (2004). Participatory budgets in Europe. Between efficiency and growing local 'democracy'. In: Transnational Institute and the Centre for democratic policy-making, TNI briefing series. No. 2004/5.

ANDERSEN, H. T. and VAN KEMPEN, R. (2003). New trends in urban policies in Europe: Evidence from the Netherlands and Denmark. In: Cities. Vol. 20, pp. 77-86. DOI: 10.1016/S0264-2751(02)00116-6.

ARVANITIDIS, P. A. (2017). The concept and determinants of civic engagement. In: Human Affairs. Vol. 27, No. 3, 2017, pp. 252-272. DOI: https://doi.org/10.1515/humaff-2017-0022.

BARDOVIČ, J. and GAŠPARÍK, J. (2021). Enablers of Participatory Budgeting in Slovakia During the COVID-19 Pandemic. In: Scientific Papers of the University of Pardubice, Series D: Faculty of Economics and Administration, Vol. 29, No. 1, Art. No. 1248. DOI: https://doi.org/10.46585/sp29011248. BIRSKYTE, L. (2013). Involving citizens in public decision making: the case of participatory budgeting in Lithuania. In: Public Sector Economics. Vol. 37, No. 4, pp. 383-402. DOI: https://doi.org/10.3326/fintp.37.4.3.

BLOOMFIELD, D., COLLINS, K., FRY, C. and MUNTON, R. (2001). Deliberation and inclusion: Vehicles for increasing trust in UK public governance? In: Environment and Planning C: Government and Policy. Vol. 19, pp. 501-513. DOI: https://doi.org/10.1068/c6s.

BUČEK, J. and SMITH, B. (2000). New approaches to local democracy: Direct democracy, participation and the "third sector". In: Environment and Planning C: Government and Policy. Vol. 18, No. 1, pp. 3-17. DOI: https:// doi.org/10.1068/c9950.

CARLITZ, R. (2013). Improving Transparency and Accountability in the Budget Process: An Assessment of Recent 'Initiatives. In: Development Policy Review. Vol. 31, No. 1, pp. 49-67. DOI: https://doi.org/10.1111/ dpr.12019.

CHO, C.H., JÉRÔME, T. and MAURICE, J. (2021). "Whatever it takes": first budgetary responses to the COVID-19 pandemic in France. In: Journal of Public Budgeting, Accounting \& Financial Management. Vol. 33, No. 1, pp. 12-23. DOI: https://Doi.Org/10.1108/Jpbafm-07-2020-0126.

COOPER, T. L., BRYER, T. A. and MEEK, J. W. (2006). Citizen-centered collaborative public management. In: Public Administration Review, Vol. 66, pp. 76-88. DOI: https://doi.org/10.1111/j.1540-6210.2006.00668.x. 
COUNCIL OF EUROPE, CENTRE OF EXPERTISE. (2018). 12 principles of good democratic governance. [online]. Available at: https://rm.coe.int/ brochure-12-principles-of-good-governance-and-current-tools-ongood-go/16808b1687 [Accessed April 3, 2020].

DE RENZIO, P. and WEHNER, J. (2017). The Impacts of Fiscal Openness. In: The World Bank Research Observer. Vol. 32, No. 2, pp. 185-210. DOI: https://doi.org/10.1093/wbro/lkx004.

DŽINIĆ, J., MURRAY SVIDROŇOVÁ, M. and MARKOWSKA-BZDUCHA, E. (2016). Participatory Budgeting: A Comparative Study of Croatia, Poland and Slovakia. In: NISPAcee Journal of Public Administration and Policy. Vol. 9, No. 1, pp. 31-56. DOI: https://doi.org/10.1515/nispa-2016-0002. EBDON, C. (2000). The Relationship Between Citizen Involvement in the Budget Process and City Structure and Culture. In: Public Productivity and Management Review. Vol. 23, No. 3, pp. 383-393. DOI: https://doi. org/10.2307/3380726.

FUNG, A. (2006). Varieties of participation in complex governance. In: Public Administration Review. Vol. 66, pp. 66-75. DOI: https://doi.org/10.1111/ j.1540-6210.2006.00667.x.

GOETZ, A. M. and GAVENTA, J. (2001). Bringing Citizen Voice and Client Focus into Service Delivery. Working Paper 138. Brighton, UK: Institute of Development Studies, $65 \mathrm{pp}$.

HALACHMI, A. and HOLZER, M. (2010). Citizen Participation and Performance Measurement: Operationalizing Democracy through Better Accountability. In: Public Administration Quarterly. Vol. 34, No. 3, pp. 378-399. DOI: https://doi.org/10.2307/41288353.

HARRISON, T. M. and SAYOGO, D. S. (2014). Transparency, Participation, and Accountability Practices in Open Government: A Comparative Study. In: Government Information Quarterly. Vol. 31, No. 4, pp. 513-525. DOI: https://doi.org/10.1016/j.giq.2014.08.002.

HAYRAPETYAN, R. (2019). Quantitative Analysis of Factors Affecting Citizen Participation in Local Governance: The Case of Yerevan. In: Public Administration Issue. No. 6. (Special Issue II, electronic edition), pp. 6176. DOI: https://doi.org/10.17323/1999-5431-2019-0-6-61-76.

KLIMOVSKÝ, D. and MURRAY SVIDROŇOVÁ, M. (2021). Political determinants of sustainable participatory budgeting in Slovakia. Presented at IR SPM Conference 2021 - Public Management, Governance and Policy in Extraordinary Times: Challenges and Opportunities, 20-23 April 2021. 
KLUN, M. and BENČINA, J. (2022). Experiences of participatory budgeting in Slovenian municipalities. In: De Vries, M., Nemec, J. and Spacek, D. International Trends in Participatory Budgeting. Springer, forthcoming. KUKUČKOVA, S. and BAKOŠ, E. (2019). Does Participatory Budgeting Bolster Voter Turnout in Elections? The Case of the Czech Republic. In: NISPAcee Journal of Public Administration and Policy, Vol. 12, No. 2, pp. 109-129. DOI: https://doi.org/10.2478/nispa-2019-0016.

LEHTONEN, P. (2021). Policy on the move: the enabling settings of participation in participatory budgeting. In: Policy Studies, March, 2021. DOI: https://doi.org/10.1080/01442872.2021.1895981.

LIAO, Y. and ZHANG, Y. (2012). Citizen Participation in Local Budgeting: Mechanisms, Political Support, and City Manager's Moderating Role. In: International Review of Public Administration. Vol. 17, No. 2, pp. 19- 38. DOI: https://doi.org/10.1080/12294659.2012.10805226.

MANES-ROSSI, F., BRUSCA, I., LEVY ORELLI, R., LORSON, P. C. and HAUSTEIN, E. (2021). Features and Drivers of Citizen Participation: Insights from participatory budgeting in three European cities. In: Public Management Review. August 2021, DOI: https://doi.org/10.1080/14719037.2021.19 63821.

MBITHI, A., NDAMBUKI, D. and JUMA, F. (2019).Determinants of Public Participation in Kenya County Governments. In: Journal of Asian and African Studies. Vol. 54, No. 1, pp. 52-69. DOI: https://doi. org/10.1177\%2F0021909618794028.

MEMETI, M. and KRECI, V. (2016). Role of the Municipal Council in Increasing Citizen Participation at the Local Budget Process. In: Central European Public Administration Review. Vol. 14, No. 2-3, pp. 53-73. DOI_ https:// doi.org/10.17573/ipar.2016.2-3.03.

MILLER, S. A., HILDRETH, R.W. and STEWART, L. M. (2019). The Modes of Participation: A Revised Frame for Identifying and Analyzing Participatory Budgeting Practices. In: Administration \& Society. Vol. 51, No. 8, pp. 12541281. DOI: https://doi.org/10.1177/0095399717718325.

MOYNIHAN, D. P. (2007). Citizen Participation in Budgeting: Prospects for Developing Countries. In: Shah, A. et al. Participatory Budgeting. Washington: World Bank, pp. 55-87.

NITZSCHE, P., PISTOIA, A. and ELSÄßER, M. (2012). Development of an Evaluation Tool for Participative E-Government Services: A Case Study of Electronic Participatory Budgeting Projects in Germany. In: Administratie si Management Public. Vol. 2012, No. 18, pp. 6-25. 
ORGANIZATION FOR ECONOMIC CO-OPERATION AND DEVELOPMENT. (2001). Citizens as partners. Information, consultation and public participation in policy-making. OECD: Paris.

RADU, B. (2019). The Impact of Transparency on the Citizen Participation in Decision- Making at the Municipal Level in Romania. In: Central European Public Administration Review. Vol. 17, No. 1, pp. 111-130. DOI: https:// doi.org/10.17573/cepar.2019.1.06.

RAICH, U. (2005). Fiscal Determinants of Empowerment. World Bank Policy Research Working Paper 3705. Washington: World Bank.

RIOS, A. M., BENITO, B. and BASTIDA, F. (2016). Research and Evaluation

Factors Explaining Public Participation in the Central Government Budget Process. In: Australian Journal of Public Administration. Vol. 76, No. 1, pp. 48-64. DOI: https://doi.org/10.1111/1467-8500.12197.

RUSSON, G. H. (2016). Participatory Budgeting and Civic Tech : The Revival of Citizen Engagement. Washington DC: Georgetown University Press.

SAEBO, O., ROSE, J. and FLAK, L. S. (2008). The shape of eParticipation: Characterizing an emerging research area. In: Government Information Quarterly. Vol. 25, pp. 400-428. DOI: https://doi.org/10.1016/j. giq.2007.04.007.

SHAH, A. (ed) (2007). Participatory budgeting. Washington: The World bank. SINTOMER, Y., HERZBERG, C., RÖCKE, A. and ALLEGRETTI, G. (2012). Transnational Models of Citizen Participation: The Case of Participatory Budgeting. In: Journal of Public Deliberation. Vol. 8, No. 2. DOI: https:// doi.org/10.16997/jdd.141.

SINTOMER, Y., RÖCKE, A. and HERZBERG, C. (2016). Participatory Budgeting in Europe: Democracy and public governance (1st ed.). Routledge. DOI: https://doi.org/10.4324/9781315599472.

ŠVALJEK, S., RAŠIĆ BAKARIĆ, I. and SUMPOR, M. (2019). Citizens and the city: the case for participatory budgeting in the City of Zagreb. In: Public Sector Economics, Vol. 43, No. 1, pp. 21-48. DOI: https://doi.org/10.3326/ pse.43.1.4.

TANAKA, S. (2007). Engaging the Public in National Budgeting: A NonGovernmental Perspective. In: OECD Journal on Budgeting. Vol. 7, No. 2, pp. 139-177. DOI: https://doi.org/10.1787/16812336.

THOMAS, J. C. and STREIB, G. (2005). E-Democracy, E-Commerce, and E-Research: Examining the electronic ties between citizens and governments. In: Administration \& Society. Vol. 37, pp. 59-280. DOI: https://doi.org/10.1177/0095399704273212. 
WAMPLER, B. (2000). A Guide to Participatory Budgeting. Available at: https://web.worldbank.org/archive/website01531/WEB/IMAGES/ AGUIDETO.PDF [accessed April 3, 2021].

WAMPLER, B. (2007). A guide to participatory budgeting,. In: Shah, A. et al. Participatory Budgeting. Washington: World Bank, pp. 21-54. Available at: http://documents.worldbank. org/ curated/ en/ 708251468338965560/ Participatorybudgeting [Accessed 30 April 2021].

WANG, X. (2001). Assessing public participation in US 'cities'. In: Public Performance \& Management Review. Vol. 24, No. 4, pp. 322-336. DOI: https://doi.org/10.2307/3381222.

WARREN, A. M., SULAIMAN, A. and JAAFAR, N. I. (2014). Social media effects on fostering online civic engagement and building citizen trust and trust in institutions. In: Government Information Quarterly. Vol. 31, pp. 291301. DOI: https://doi.org/10.1016/j.giq.2013.11.007.

WELLMAN, B., BOASE, J. and CHEN, W. (2002). The networked nature of community: Online and offline. In: IT \& Society. Vol. 1, No. 1, pp. 151-165.

YANG, K. F. and CALLAHAN, K. (2007). Citizen involvement efforts and bureaucratic responsiveness: Participatory values, stakeholder pressures, and administrative practicality. In: Public Administration Review. Vol. 67, pp. 249-264. DOI: https://doi.org/10.1111/j.1540-6210.2007.00711.x.

YETANO, A. (2015). Keeping Citizens Engaged. In: Administration \& Society, Vol. 49, No. 3, pp. 1-29. DOI: 10.1177/0095399715581625

ZHANG, Y. and LIAO, Y. (2011). Participatory Budgeting in Local Government: Evidence from New Jersey Municipalities. In: Public Performance and Management Review. Vol. 35, No. 2, pp. 281-301. DOI: https://doi. org/10.2753/PMR1530-9576350203.

ZHANG, Y. and YANG, K. (2009). Citizen Participation in the Budget Process: The Effect of City Managers. In: Journal of Public Budgeting, Accounting and Financial Management. Vol. 21, No. 2, pp. 289-317. DOI: https://doi. org/10.1108/JPBAFM-21-02-2009-B006. 